\title{
ANAESTHETIC ACTION OF MAGNESIUM IONS ${ }^{\star}$
}

\author{
G. KATO, Ph.D., J. S. Kelly, M.D., K. KRNJEVIć, M.D., AND G. SOMJEN, M.D.†
}

THE IDEA that magnesium might be a useful central anaesthetic was first suggested by Meltzer and Auer. ${ }^{1}$ Intravenous magnesium sulphate was in fact used as an anaesthetic on human patients by Peck and Meltzer in $1916 .{ }^{2}$ However, doubts have always existed about any central actions of parenteral administrations of magnesium. ${ }^{3-5}$

This problem was recently re-investigated by Somjen, Hilmy, and Stephen," who tested the effects of slow intravenous infusion of magnesium sulphate on human subjects. It was found that even after a large increase in plasma magnesium level-by a factor of 10 , which led to a deep paralysis of skeletal musclesthe subjects remained fully aware of their surroundings and were capable of feeling pain keenly. It was concluded from this experiment that neither anaesthesia nor even analgesia can be produced by systemic administrations of magnesium.

Although very little evidence is available about the effects of magnesium applied directly to the brain, previous studies suggest that it has a depressant action on neural or synaptic activity. For example Libet and Gerard ${ }^{7}$ observed depression of spontaneous activity in the isolated frog brain, and Feldberg ${ }^{8}$ found that infusions of magnesium into the cerebral ventricles of cats induce a sleep-like state. Katz and Miledi ${ }^{9}$ produced with magnesium a marked block of synaptic transmission in the isolated frog spinal cord.

The failure of systemic administration of magnesium to change the state of consciousness in humans might therefore well be the result of an effective bloodbrain barrier, which prevents the systemically administered magnesium from reaching the central nervous system. Several authors have in fact shown that such a blood-brain barrier does exist. Cloetta et al., ${ }^{5}$ Kemeny, Boldiszar, and Pethes, ${ }^{10}$ and Schain ${ }^{11}$ found little change in the brain or cerebrospinal fluid magnesium concentration after large injections of magnesium into the blood stream. Recent experiments by Hilmy and Somjen ${ }^{12}$ have confirmed this view, by showing only small changes in brain magnesium concentration after large intravenous injections of magnesium chloride.

In the present experiments we have investigated the effects of micro-applications of magnesium in the central nervous system of cats. It was shown earlier ${ }^{13}$ that both calcium and magnesium applied iontophoretically from micropipettes in the cerebral cortex of cats had a marked depressant action on cortical neurones; this seemed to be mainly post-synaptic depression, since there was a large reduction in sensitivity to applied excitatory substances. A similar technique was

- Presented at the Annual Meeting, Canadian Anaesthetists' Society, May 13-16, 1968.

†Wellcome Department of Research in Anaesthesia, McGill University. Dr. Kato and Dr. Krnjevic received financial support from the Canadian Medical Research Council. Dr. Kelly is a Wellcome Fellow. Dr. Somjen was on leave from Duke University, North Carolina.

Can. Anaes. Soc. J., vol. 15, no. 6, November 1968 
used in the present experiments to examine the effect of magnesium on individual cells in different parts of the cNs. For further confirmation, we also utilized intracellular electrodes to record more precisely changes in membrane properties caused by the extracellular applications of small amounts of magnesium. ${ }^{14,15}$

\section{METHODS}

The experiments were done on cats anaesthetized with Dial-urethane compound. In the first part of the investigation single units were studied with fivebarrelled micropipettes. ${ }^{16}$ These micropipettes make it possible to examine a nerve cell in situ and to study the effects of excitatory or depressant compound released from one or another barrel, singly or in various combinations. Excitatory responses were evoked by small applications of glutamic acid or acetylcholine, and magnesium was released from a concentrated solution of magnesium chloride $(0.5 \mathrm{M})$. In the second half of the investigation intracellular recording was combined with microiontophoretic applications by using the double electrode system described by Krmjević \& Schwartz. ${ }^{17}$ The micropipette used for intracellular recording was filled with potassium acetate or glutamate $(0.5-1 \mathrm{M})$. A balanced bridge input made it possible to feed pulses of current into the pipette to measure changes in membrane resistance as well as in membrane potential.

\section{Extracellular studies}

\section{RESULTS}

\section{A. Cerebral cortex}

Spontaneous and synaptically evoked firing. All cells firing spontaneously or excited by stimulating a suitable thalamic nucleus showed a substantial depression by the application of magnesium in doses of $10-100 \mathrm{nA}$.

Excitation evoked by glutamate or acetylcholine. Most cortical cells can be excited by small amounts of glutamate; ${ }^{16}$ this provides a useful way of testing changes in excitability. All the cortical cells which were tested with magnesium under these conditions showed a very marked depressant action, even with very small amounts of magnesium (as little as $20 \mathrm{nA}$ ). Most cortical cells which could be excited by local applications of acetylcholine ${ }^{18}$ were strongly depressed by the release of magnesium. In all cases the action of magnesium had a rapid onset and the excitability returned within 20 seconds after the application was stopped.

\section{B. Cuneate nucleus}

Responses evoked synaptically. Many cuneate cells can be excited by electrical stimulation of peripheral nerves (e.g. superficial radial) or by a suitable stimulation of receptors in the skin or joints of the foreleg. This type of activity was readily blocked by the application of magnesium.

Responses evoked by glutamate. Just like cortical cells, cuneate cells usually were excited easily by small amounts of glutamate and this type of activity was again very readily blocked by small amounts of magnesium. 


\section{Spinal cord: Renshaw cells}

Responses evoked synaptically. Renshaw cells are particularly convenient for analysis because they can be excited by antidromic activation of the motor roots and are excited by a cholinergic mechanism just like muscle fibres at the periphery. ${ }^{19}$ This should therefore be a particularly favourable site for demonstrating a pre-synaptic blocking action of magnesium, comparable to the well-known effect in muscle. ${ }^{20}$ Iontophoretic applications of $10-80 \mathrm{nA}$ of magnesium caused a substantial but reversible reduction of the repetitive response normally evoked by antidromic stimulation.

Responses evoked by acetylcholine and glutamate. Renshaw cells can be made to fire at a high frequency by small amounts of acetylcholine. This excitation was blocked by magnesium. Comparable effects were seen with other spinal neurones.

\section{Intracellular studies}

These investigations were done entirely on cortical neurones in the sensorimotor cortex of the cat. Systematic studies of over 50 neurones showed that doses of magnesium varying between 10-100 nA produced little or no change in membrane potential and did not markedly affect synaptic potentials occurring spontaneously or evoked by cortical stimulation. Magnesium also produced only small changes in membrane resistance; if anything there was a small tendency towards an increase in the membrane resistance.

However, we observed consistently a marked increase in the electrical threshold of the cells, as tested with pulses of current introduced through the recording electrode, or by a steady depolarization. Magnesium either reduced the number of spikes elicited by given suprathreshold stimulus, or stopped the neuronal firing altogether. This action was quick in onset and rapidly reversible.

A number of "unresponsive" cells-which can be shown to be mainly glia (oligodendrocytes) ${ }^{21}$-were also investigated. These cells, of course, are not excitable, but their membrane resistance tended to rise during an application of magnesium.

In general all the cells (neurones or glia) which were tested in the same way with calcium showed a very similar kind of effect; that is, a large reduction in electrical excitability-not accompanied by any marked changes in membrane potential-and a variable tendency toward an increase in resistance.

\section{Discussion AND SUMMARY}

The best known effect produced by magnesium on synaptic transmission is a large reduction in the amount of chemical transmitter released from synaptic terminals. This effect has been studied particularly in muscle, where it has been shown that the quantal release of acetylcholine is inversely related to the concentration of magnesium in the surrounding fluid, and that the blocking action of magnesium can be reversed by increasing the local calcium concentration. ${ }^{20}$ Del Castillo \& Engbaek, ${ }^{22}$ however, have shown that small changes in the electrical excitability of muscle fibres are associated with the action of magnesium, 
so that the whole effect of magnesium is not entirely at the pre-synaptic site. It is known from previous experiments on nerve fibres ${ }^{23-25}$ that magnesium, like calcium, depresses excitability. Some depressant effect was therefore not unexpected.

What is particularly striking is that in the three different regions of cNs studied, there was no sign of any pre-synaptic action of magnesium comparable with that observed at the neuromuscular junction. In every case there was clear evidence of a mainly post-synaptic depression of excitability, shown by the marked inactivation of responses to glutamate or acetylcholine. (Glutamate has no detectable effect on pre-synaptic terminals. ${ }^{26}$ ) The post-synaptic site of action of magnesium was confirmed by measurements of membrane excitability, tested by intracellular recording and by the application of intracellular current pulses, which consistently showed a sharp reduction of excitability not associated with any consistent and marked changes in membrane potential or resistance.

It is clear that the depressant action of magnesium is not a result of a specific increase in permeability towards chloride and/or potassium ions as in the typical inhibitory effect seen during inhibitory synaptic potentials and the application of GABA and other inhibitory amino acids. ${ }^{17,27}$ The action of magnesium is therefore likely to result from a "stabilizing" effect on the cell membrane. ${ }^{28}$ It must be supposed that small amounts of magnesium can interact with the critical membrane groups that control ionic movements leading to excitation (particularly the influx of $\mathrm{Na}^{+}$). Magnesium thus acts very much like calcium, which has a similar depressant action, presumably because both divalent ions are particularly effective in neutralizing surface charges.

The very potent effects of magnesium (and calcium) on central cells are thus of much interest. They could play a significant role in the control of excitability of central cells, small changes in magnesium concentration being reflected in very large changes in level of activity and in behaviour. In any case it is clear that the blood-brain barrier plays an essential role in protecting the central nervous system from the marked fluctuations in plasma magnesium concentration which must occur under normal conditions.

\section{RÉSUMÉ}

Le meilleur effet connu que produit le magnésium sur la transmission synaptique est une diminution considérable de la quantité du véhicule chimique libéré aux terminaisons synaptiques. Cet effet a été étudié plus particulièrement sur le muscle, où il a été montré que la quantité d'acétylcholine libérée est inversement proportionnelle à la concentration de magnésium dans les liquides environnants et que le pouvoir de blocage du magnésium peut être inhibé en augmentant la concentration locale de calcium. Toutefois, en 1954, Del Castillo et Engback ont montré que seulement de faibles modifications de l'excitabilité électrique du muscle sont attribuables à l'action du magnésium, de sorte que l'effet total des magnésium ne s'exerce pas complètement au niveau présynaptique. Des études antérieures nous ont appris que laction du magnésium, comme celle du calcium 
d'ailleurs, sur les fibres nerveuses est une action de dépression de l'excitabilité. C'est pour cela d'ailleurs que la constatation d'une dépression ne nous a pas surpris.

Ce qui nous a surpris plus particulièrement c'est que, dans les trois différentes sections du système nerveux central que nous avons étudiées, l'action présynaptique du magnésium n'était pas comparable à celle que nous avons observée à la jonction neuromusculaire. Dans chaque cas il y avait évidence de dépression de l'excitabilité surtout post-synaptique démontrée par l'inactivation prononcée des réponses aux glutamates ou à l'acétylcholine. (Le glutamate n'a pas d'effets décelables sur les terminaisons présynaptiques.) Le site d'action post-synaptique du magnésium a été déterminé en mesurant l'excitabilité de la membrane, évaluée par l'enregistrement intracellulaire et par l'application d'ondes de courant intracellulaire, ce qui a démontré de façon constante une forte réduction de l'excitabilité non reliée à des changements prononcés et prolongés du potentiel ou de la résistance de la membrane.

Il est manifeste que laction dépressive du magnésium ne résulte pas de l'augmentation spécifique de la perméabilité pour le chlorure et/ou pour les ions potassium comme dans l'effet inhibiteur typique observé durant les potentiels synaptiques inhibiteurs et l'application de GABA et d'autres acides aminés inhibiteurs. L'action du magnésium résulte, selon toute vraisemblance, d'un effet stabilisateur de la membrane cellulaire. Il faut supposer que de petites quantités de magnésium peuvent influencer les groupes critiques de la membrane qui controlent les mouvements ioniques conduisant à l'excitation (particulièrement l'entrée du $\mathrm{Na}^{+}$). Ainsi l'action du magnésium ressemble à celle du calcium, qui exerce une action dépressive semblable, probablement parce que les deux sont des ions divalents et particulièrement capables de neutraliser les charges de surface.

Les effets très marqués du magnésium (et du calcium) sur les cellules centrales présentent donc un grand intérêt. Ils peuvent jouer un rôle important dans le contrôle de l'excitabilité des cellules centrales : de faibles modifications dans la concentration du magnésium produisant des changements très importants dans le niveau d'activité et dans le comportement. En toute éventualité, il est manifeste que le barrage sang-cerveau joue un rôle essentiel dans la protection du système nerveux central contre les fluctuations trop grandes dans la concentration plasmatique de magnésium qui peuvent survenir en temps normal.

\section{REFERENCES}

1. Mentzer, S. J. \& Auer, J. Physiological and Pharmacological Studies of Magnesium Salts: I. General Anesthesia by Subcutaneous Injections. Am. J. Physiol. 14: 366 (1906).

2. Peck, C. H. \& Meltzer, S. J. Anesthesia in Human Beings by Intravenous Injection of Magnesium Sulphate. J.A.M.A. 67: 113 (1916).

3. Gutrrie, C. C. \& Ryan, A. H. On the Alleged Specific Anaesthetic Properties of Magnesium Salts. Am. J. Physiol. 26: 329 (1910).

4. HoFf, H. E.; SMmth, P. K.; \& WinkLER, A. W. Effects of Magnesium on the Nervous System in Relation to Its Concentration in Serum. Am. J. Physiol. 130: 292 (1940).

5. Cloetta, M.; Fischen, H.; \& van den LoefF, M. R. Die Verteilung und die Wirkung des Magnesiums im Organismus und deren Beeinflussung durch Calcium. Arch. exper. Pathol. Pharmark. 200: (1942). 
6. Somjen, G.; Hilmy, M.; \& Stephen, C. R. Failure to Anesthetize Human Subjects by Intravenous Administration of Magnesium Sulfate. J. Pharmacol. Exper. Therap. 154: $652(1966)$.

7. Libet, B. \& Gerard, R. W. Control of the Potential Rhythm of the Isolated Frog Brain. J. Neurophysiol. 2: 153 (1939).

8. Feldeerg, W. A Pharmacological Approach to the Brain from Its Inner and Outer Surface. London: Arnold (1963).

9. Katz, B. \& MrLedr, R. A Study of Spontaneous Miniature Potentials in Spinal Motoneurones. J. Physiol. 168: 389 (1963).

10. Kemeny, A.; Bolmizsar, H.; \& Pethes, G. The Distribution of Cations in Plasma and Cerebrospinal Fluid Following Infusion of Solutions of Salts of Sodium, Potassium, Magnesium, and Calcium. J. Neurochem. 7: 218 (1961).

11. Schain, R. J. Cerebrospinal Fluid and Serum Cation Levels. Arch. Neurol. 11: 330 (1964).

12. Hilmy, M. I. \& Somjen, G. Distribution and Tissue Up-take of Magnesium Related to Its Pharmacological Effects, Am. J. Physiol. 214: 406 (1968).

13. Krnjevic, K. Actions of Drugs on Single Neurones in the Cerebral Cortex. Brit. Med. Bull. 21: 10 (1965).

14. Somjen, G. \& Kato, G. Effects of Micro-iontophoretic Administration of $\mathrm{Mg}$ and Ca on Neurons in the Central Nervous System, Exper. Brain Res. (In press.)

15. Kelly, J. S.; KrNJevic, K. \& Somjen, G. Effects of $\mathrm{Ca}^{++}$and $\mathrm{Mg}^{++}$on Membrane Properties of Cortical Cells. Proc. XXIV Internat. Congress Physiol. Sc. (Washington). 7: 233 (1968)

16. Krnjević, K. \& Prmlis, J. W. Iontophoretic Studies of Neurones in the Mammalian Cerebral Cortex. J. Physiol. 165: 274 (1963).

17. Krnjević, K. \& Schwartz, S. The Action of $\gamma$-aminobutyric Acid on Cortical Neurones. Exper. Brain Res. 3: 320 (1967).

18. Krnjević, K. \& Primlis, J. W. Acetylcholine-sensitive Cells in the Cerebral Cortex. J. Physiol. 166: 296 (1963).

19. Eccles, J. C.; FatT, P.; \& Koketsu, K. Cholinergic and Inhibitory Synapses in a Pathway from Motor-axon Collaterals to Motoneurones. J. Physiol. 126: 524 (1954).

20. Del Castillo, J. \& Katz, B. Biophysical aspects of Neuro-muscular Transmission. Prog. Biophys. 6: 122 (1956).

21. Kelly, J. S.; Krovjevid, K.; \& YMa, G. K. W. Unresponsive Cells in Cerebral Cortex. Brain Research. 6: 767 (1967).

22. Del Castillo, J. \& Encbaek, L. The Nature of Neuromuscular Block Produced by Magnesium. J. Physiol. 124: 370 (1954).

23. Woronzow, D. S. Ueber die Einwirkung des konstanten Stromes auf den mit Wasser, Zuckerlösung, Alkali- und Erdalkalichloridlösungen behandelten Nerven. Pflüg. Arch. ges. Physiol. 203: 300 (1924).

24. Encbaek, L. The Pharmacological Actions of Magnesium Ions with Particular Reference to the Neuromuscular and Cardiovascular System. Pharmacol. Rev, 4: 396 (1952).

25. Frankentraeusen, B. \& Meves, H. The Effect of Magnesium and Calcium on the Frog Myelinated Nerve Fibre. J. Physiol. 142: 360 (1958).

26. Galindo, A. Some Observations on Presynaptic Action of Drugs, Including Anaesthetic Agents, in the Cuneate Nucleus. Fed. Proc. 27: 756 (1968).

27. Werman, R.; Davmoff, R. A.; \& Aprison, M. H. Inhibitory Action of Glycine on Spinal Neurons in the Cat. J. Neurophysiol. 31: 81 (1968).

28. Shanes, A. M. Electrochemical Aspects of Physiological and Pharmacological Action in Excitable Cells. Pharmacol. Rev. 10:59 (part I), 165 (part II) (1958). 